COMMENTARIES \& NOTES

\title{
Appreciation: Lankabhimanya Sir Arthur C. Clarke
}

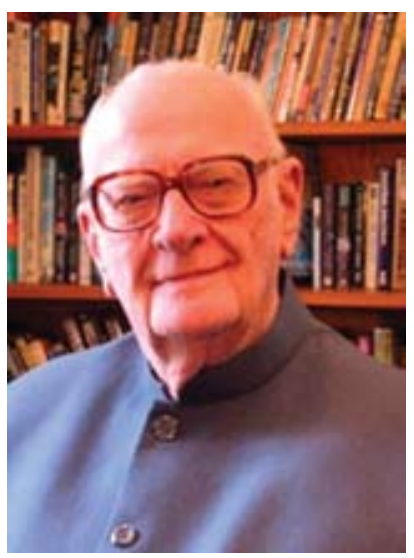

Sir Arthur C. Clarke, popularly known as Sir Arthur, born at Meinhead in the U.K., chose to live in Sri Lanka from 1956. Thus he enriched Sri Lanka with his vision, writings and predictions and brought fame to this island for a period of over half a century.

Sir Arthur was known to many as a superb science fiction writer. His fiction had a specialty; they were based on some fundamental scientific elements and therefore many of the creations were not impossibles. Similar events could actually materialize some day - in a few years or few centuries. Perhaps his early scientific background, experience at the Royal Air Force, U.K. during the Second World War as a RADAR technician and the Bachelors' degree he earned subsequently at Kings College, London in mathematics and physics enabled him to author realistic science fiction. He also wrote a number of popular nonfiction books and technical articles.

The most acknowledged of the technical articles which Sir Arthur published is the article titled "Extraterrestrial Relays: Can Rocket Stations Give Worldwide Radio Coverage?" in the Journal "Wireless World" U.K. in October, 1945. He calculated and showed that at $36,000 \mathrm{~km}$ above the equator, it was possible to have geo-stationary satellites and with three such satellites properly placed in orbit, global communication could be achieved. This was long before man-made satellites were launched. At the Arthur C. Clarke Institute for Modern Technologies (ACCIMT), we are particularly grateful to him for this great work.
Sir Arthur C. Clarke loved and cared for nature. In Sri Lanka, he first settled down at Unawatuna on the south cost. He enjoyed scuba diving and was very interested in under-water exploration. Indeed, he was an explorer of under water and above water, one could say covering the entire universe.

In the early part of nineteen eighties, the government was interested in setting up a Centre for Modern Technologies. A bill to bring in legislation through Parliament was prepared around 1983. The scientists and administrators associated with this preparation thought that it would be great to associate Arthur C. Clarke with this modern technologies institution. When contacted, Sir Arthur readily agreed to lend his name. Not only did he help by lending his name but also went on to donate the prize money he received from the prestigious Marconi Award. The initial equipment was obtained through a UN grant and the government undertook to bear the recurrent expenditure including salaries of staff. Thus, the Arthur C. Clarke Centre for Modern Technologies was born. Later, by another Act of Parliament (Science \& Technology Development Act No.11 of 1994), the centre was renamed as the Arthur C. Clarke Institute for Modern Technologies. Sir Arthur C. Clarke was the Patron of this institute until he passed away in March 2008.

As the honorary Patron, Sir Arthur often graced the ceremonial functions of the Institution. He was a real inspiration and provided much guidance to the Institute and its staff. He was kind, humane and generous. Sir Arthur donated a large number of books to the library of the ACCIMT, including those authored by him and others. The Institute will continue to benefit from these valuable collections.

Sir Arthur C. Clarke also functioned as the Chancellor of the University of Moratuwa from 1972 to 2002. 
He was awarded an honorary doctorate by the University of Moratuwa in recognition of his achievements and services.

Sir Arthur C. Clarke was nominated for a Nobel Peace Prize and a Nobel Literature Prize in 1994 and 1999 respectively. In 2000, he was knighted by the United Kingdom in a ceremony held in Colombo. The 2001 Mars Odyssey orbiter is named in honour of his work. On the $14^{\text {th }}$ of November, 2005, Sir Arthur C. Clarke was conferred Sri Lanka's highest civilian award, the 'Sri Lankabhimanya' (The Pride of Sri Lanka), for his contributions to science and technology and his commitment to his adopted country.
The staff at the Arthur C. Clarke Institute for Modern Technologies will fondly remember Sir Arthur. So will the public of Sri Lanka.

\section{Vidya Jyothi Prof. K.K.Y.W. Perera}

Chairman

Arthur C. Clarke Institute for Modern Technologies

- Editorial Office 